\title{
A study of off-label and unlicensed medicines use in neonatal units
}

\author{
Elizabeta Zisovska $^{1 *}$, Blerina Koshi ${ }^{2,3}$, Renata Slaveska-Raichki ${ }^{3}$ \\ ${ }^{1}$ University Clinic for Gynecology and Obstetrics, Vodnjanska 17, 1000 Skopje, \\ Republic of Macedonia \\ ${ }^{2}$ Department of Pharmacy, Faculty of Medicine, University of Prishtina "Hasan Prishtina", \\ Martyrs Square nn, 10000 Prishtina, Republic of Kosovo \\ ${ }^{3}$ Faculty of Pharmacy, University "Ss Cyril and Methodius", Mother Teresa 47, 1000 Skopje, Republic of Macedonia
}

Received: November 2016; Accepted: December 2016

\begin{abstract}
Despite all efforts to improve the on-label use of licensed medicines for neonates, there is still high percentage and demands of offlabel and unlicensed medicines use in neonatal therapy. Therefore, the general objective of this survey is to provide a description of off-label and unlicensed medicines use within the neonatal therapeutic areas in a Department of Neonatology, University Clinic for Gynecology and Obstetrics, in Skopje, Republic of Macedonia. All analyzed prescriptions were given in accordance with the Evidence Based Guidelines applied in the Department. During the three months' period in 2015, there were given 1595 prescriptions, comprising 3.99 prescriptions per newborn during the hospital stay. Out of them, $532(33.3 \%)$ were on-label medicine uses, 1052 (66\%) were off-label medicines, and 11 prescriptions $(0.7 \%)$ were unlicensed medicines. The results from this study show the high level of off-label medicine use in neonatal therapy. These results present only the "top of the iceberg" and require more comprehensive analysis that will gradually evolve in a National Guideline on off-label use areas in pediatric medicine, especially for critically ill newborns who are prescribed much more life-saving medicines.
\end{abstract}

Keywords: newborns, prescriptions, off-label medicines, unlicensed medicines

\section{Introduction}

The practice of off-label prescribing and use is a complex issue with advantages and weaknesses. It refer to prescription of a registered medicine for a use that is not included in the Summary of Product Characteristics (SPC), not listed in the product information, the uses outside the terms of their product license (approval) disclaimed in the SPC (Kimland et al., 2007). This practice is a real challenge for any prescriber

\footnotetext{
*elizabeta.zisovska@ugd.edu.mk
}

since, as acknowledge, the product information will not include advice about off-label use and the medicines companies are unable to promote these practices.

The detailed description of this category of medicines is presented in Table 1, although the more frequent categories are off-label use out of: age, indication, dose/frequency and route of administration. Unlicensed or unregistered medicine use, is the use of a medicine or dosage form of a medicine that has not been evaluated nor approved by the regulatory authorities. These include medicines whose formulation is modified, those that are imported before a li- 
cense has been granted; those that are chemicals used for therapeutic purposes, new drugs/formulations produced under a "special" manufacturing license or drugs that have license in other countries but not in the certain (Pandolfini \& Bonati 2005; Cuzzolin et al., 2006).

The principal reason of off-label medicine use is to respond to unmet needs of patients in valid situations when this use is clinically appropriate or essential. There is no legal obstacle to prescribing off-label however, the prescriber should be able to justify and support off-label prescribing decision and feel competent in using such medicines. Actually, in practice, this approach is not different from what should ideally be done for the rational prescribing of any medicine.

Consequently it is a common practice in paediatric pharmacotherapy, since the labelling information about appropriate use of medicines in this population group is lacking. On the other hand, pharmaceutical researches are reluctant to enrol children in clinical trials, often based on liability fears (Dresser \& Frader 2009). Especially, neonatologists have almost no choice but to prescribe off-label or unlicensed drugs because their patients are rarely entered into trials of new medications (Palčevski et al., 2012).

While off-label medicines use is not illegal, and may sometimes be the only appropriate, it is associated with important clinical and ethical concerns which need to be considered when assessing overall benefits and risks (Bavdekar \& Gogtay 2005; Gazarian et al., 2006).

The health outcomes of unapproved medicines use in the neonatal population are not systematically evaluated, which compounds the original problem by even further limiting the evidence base for future treatment decisions. This is particularly true for safety outcomes, with gross under-reporting of adverse drug reactions, which may be even more pronounced for unapproved vs. approved uses of medicines. However, there is now accumulating evi- dence of resulting harm, with increased incidence and seriousness of adverse drug reactions associated with offlabel and unlicensed medicines use in neonates (Ufer et al., 2004; Miller et al., 2007). Even the so-called Pediatric Regulation (Regulation No 1901/2006), whose one of the key objectives is to reduce the off-label use of medicines in the pediatric population, cannot entirely solve this problem and the practice of off-label use will remain an issue $(\mathrm{Eu}-$ ropean Commission, 2013).

Therefore, the aim of this study was to investigate, analyze and present the extent and manner of use of medicines that are either outside the terms of their product license (off-label), or are unlicensed within the neonatal therapeutic areas.

\section{Materials and methods}

The setting for this research was at the Department of Neonatology within the University Clinic for Gynecology and Obstetrics, in Skopje, Republic of Macedonia. This Clinic is a tertiary level hospital care with approximately 6000 deliveries per year. The Department of Neonatology itself consists of three Units: classical Intensive Care Unit (ICU) which contains 22 intensive beds; Transitional Care Unit (TCU), containing 15 beds for full term or near term newborns that require close monitoring or therapy, but not intensive care; and Routine Care Unit (RCU) for healthy full term newborns, which are rooming in with their mothers during the whole hospital stay until discharge.

This study was designed as a pilot cohort study, prospectively conducted during the period of three months in 2014 (beginning of March -end of June) and involving 400 admitted neonates to the three units of the Department of Neonatology. The sample of patients for the study included: a) 200 successively admitted neonates to

Table 1. Detailed description of broader off-label categories

Off-label category

Description

\begin{tabular}{ll}
\hline Age & $\begin{array}{l}\text { Age ranges specified in the SPC do not include neonatal period } \\
\text { Medicine use is not recommended for the neonatal patients below a } \\
\text { certain weight in the SPC }\end{array}$ \\
$\begin{array}{l}\text { Information } \\
\text { Clinical data/trials }\end{array}$ & $\begin{array}{l}\text { Absence of information in the SPC of medicine treatment to neonatal patients } \\
\text { safety for neonates in the SPC } \\
\text { Contraindication }\end{array}$ \\
Indications & Medicine use when there is a specific contraindication to neonatal period stated in the SPC \\
Route of administration & Medicine prescribed for indications in neonatology not listed in the SPC \\
Doselfrequency & Medicine dose /frequency not stated in SPC
\end{tabular}


the ICU, 152 of them were preterm neonates and 48 full term ill neonates; b) 100 full term neonates successively admitted to the TCU; c) 100 successively born, full term healthy neonates, rooming in with their mothers in RCU. Patients were categorized based on their gestational age to preterm ( $<37$ weeks) and full-term ( $\geq 37$ weeks) newborns.

Since there were no human beings involved directly in the study (only the medication charts were analyzed, and the treatment was based on the nationally approved Clinical Guidelines), and none of the information used in the research contained any references to patient identity, it was considered ethically appropriate without official Ethical Committee approval.

Exclusion criteria regarding investigated medicines: 1) Standard intravenous replacement solutions; 2) Flushes of $0.9 \%$ sodium chloride or heparin; 3) Blood products; 4) Oxygen; 5) Vitamin supplements (except Vitamin $\mathrm{K}$ in prophylaxis); 6) Topical ointments and solutions;7) Total parenteral nutrition prepared in Hospital Pharmacy.

A data collection form was designed and used for further analysis. The data were imported and analyzed in a database (Microsoft Access, 2000). The information about all drug prescriptions were derived out from the clinical records of the admitted patients in the Department of Neonatology, and transferred to the database. Details recorded included: patient's birth number, date of birth, weight, gestational age and diagnosis, indication for drug use, medicines administered, date and route of administration, dose and frequency.

Firstly, all prescribed medicines were analyzed with regard to their license status (licensed or unlicensed) then the licensed medicines were classified in accordance to onlabel or off-label uses.

\section{Results and discussion}

In the cohort group as whole, 1595 prescriptions were given according to the medical condition and indication in accordance with the Macedonian Evidence based Guidelines applied in the Department of Neonatology (Ministry of Health, n.d.), which comprised 3.99 prescriptions per newborn during the hospital stay. Out of them, 33.3\% were on-label medicine uses, $66 \%$ were offlabel medicines, and $0.7 \%$ of prescriptions were unlicensed medicines (Table 2).

Table 2. Distribution of prescriptions according to the license status of the medicines

\begin{tabular}{lcc}
\hline $\begin{array}{c}\text { Category of } \\
\text { medicines }\end{array}$ & Prescriptions of medicines \\
\hline & $($ Total $\mathrm{n}=1595)$ & $\%$ \\
On-label & $\mathrm{n}$ & 33.3 \\
Off-label & 532 & 66.0 \\
Unlicensed & 1052 & 0.7 \\
n-number of prescriptions. & 11 &
\end{tabular}

The further analysis showed 2.63 prescriptions of offlabel medicines/newborn, 0.03 prescriptions of unlicensed medicines/newborn, and 1.33 prescriptions/newborn for licensed, on-label medicines, appropriate from each point of view (Fig. 1).

The results were more specific regarding the severity of the medical conditions of the admitted newborns, when presented in details for each Unit.

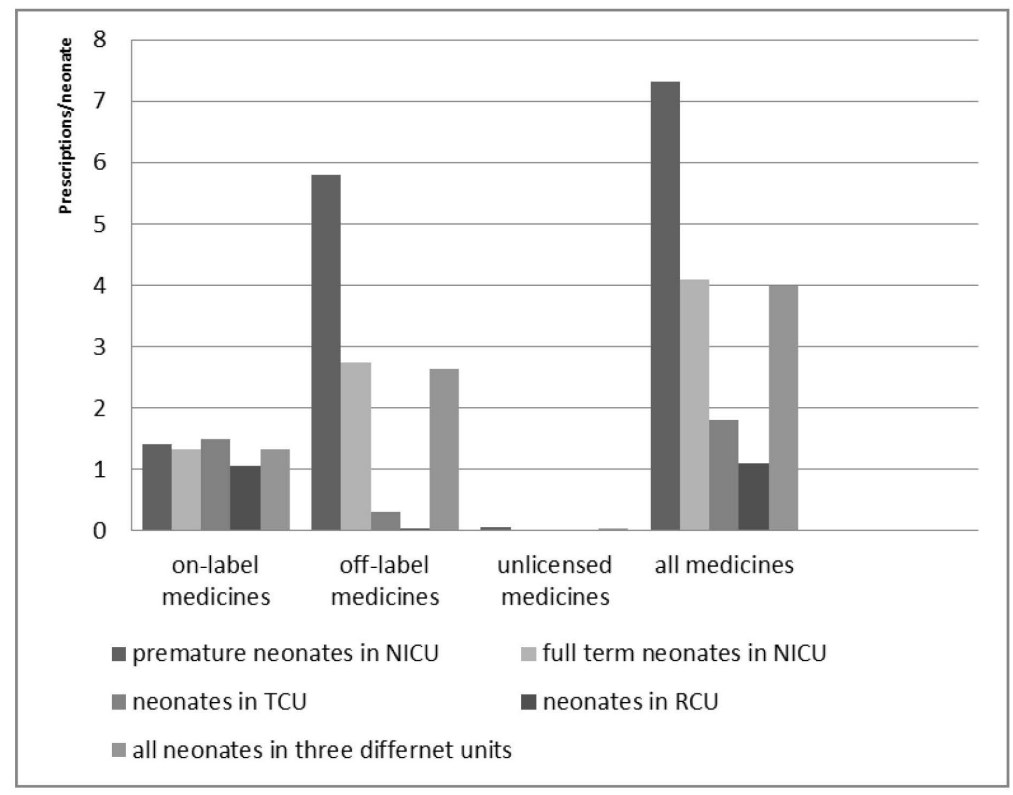

Fig. 1. Comparison of drug use among the subgroups of investigated patients.

Макед. фарм. билт., 62 (2) 65 - 72 (2016) 
Table 3. Distribution of prescriptions among the neonates (premature and full term ill) admitted to ICU

\begin{tabular}{|c|c|c|c|c|c|c|}
\hline \multirow[t]{2}{*}{ Category of medicines } & \multicolumn{2}{|c|}{$\begin{array}{c}\mathrm{P}_{1} \\
(\mathrm{pn} \mathrm{n}=152)\end{array}$} & \multicolumn{2}{|c|}{$\begin{array}{c}\mathrm{P}_{2} \\
(\text { ftin } \mathrm{n}=48)\end{array}$} & \multicolumn{2}{|c|}{$\begin{array}{c}\mathrm{P}_{3} \\
(\text { ne } \mathrm{n}=200)\end{array}$} \\
\hline & $\mathrm{n}$ & $\%$ & $\mathrm{n}$ & $\%$ & $\mathrm{n}$ & $\%$ \\
\hline On-label & 214 & 19.2 & 64 & 32.5 & 278 & 21.3 \\
\hline Off-label & 888 & 79.9 & 132 & 67 & 1020 & 77.9 \\
\hline Unlicensed & 10 & 0.9 & 1 & 0.5 & 11 & 0.8 \\
\hline All medicines & 1112 & 100 & 197 & 100 & 1309 & 100 \\
\hline
\end{tabular}

$\mathrm{P}_{1}$ - prescriptions for premature neonates in ICU; $\mathrm{P}_{2}$ - prescriptions for full term ill neonates in ICU; $\mathrm{P}_{3}$ - prescriptions for all neonates in ICU; pn n- number of premature neonates; ftin $\mathrm{n}$ - number of full term ill neonates; ne $\mathrm{n}$ - number of all neonates.

In the neonatal ICU, there were in total 6.54 prescriptions/newborn. The research came up with different results for premature neonates and full term neonates ( 7.31 and 4.1 respectively). The detailed analysis showed 1.39 prescriptions/neonate on-label medicines (premature neonate 1.4 and full term 1.33); 5.1 prescriptions/neonate off-label medicines (5.8 premature and 2.75/full term ill newborns), and $0.055 /$ neonate unlicensed medicines (0.06/premature and $0.021 /$ full term ill neonate) (Fig. 1). Out of them, $21.3 \%$ were licensed on-label medicines, $77.9 \%$ were licensed off-label medicines, and $0.8 \%$ were unlicensed medicines (Table 3).

In both units, TCU and RCU, where near term or full term neonate are admitted (not severely ill or healthy) the distribution of the prescriptions was completely different. From the medical history, the following data was retrieved: in total, there were 1.8 prescriptions/newborn in TCU; more precisely, there were 1.5 prescriptions/neonate on-label medicines; 0.3 prescriptions/neonate off-label medicines, and no unlicensed medicines (Fig. 1). Out of them, $84.1 \%$ were licensed on-label medicines, $15.9 \%$ were licensed off-label medicines. In addition, in the other Unit, the RCU, there were 1.06 prescriptions/neonate onlabel medicines, 0.04 prescriptions/neonate off-label, and no unlicensed medicines. Presented in proportions, 96.4
$\%$ were on-label and only $3.6 \%$ were off-label because of different terms of inappropriateness (Table 4).

The most frequently prescribed off-label drug at the Department of Neonatology was imipenem and five most frequently prescribed off-label drugs of all prescriptions are presented in Table 5.

To the best of our knowledge, this is the first study evaluating off-label and unlicensed drug uses in newborns in the country and in the region of South Eastern European Countries. This Clinic is a tertiary level of care hospital, where all high-risk pregnant women are transferred as "transport in utero" for further care and delivery, and thus mostly of the newborns are admitted to the NICU or TCU.

Majority of them are very preterm, or critically ill, requiring intensive care and multidrug treatment, clearly presented in Figure 1.

There was statistically significant difference in the results of off-label drug use between the premature newborns admitted in the NICU and all other groups, as follows: $\mathrm{p}<0.05$ for the difference between premature newborns in NICU and full term newborns in NICU and $\mathrm{p}<0.01$ between the premature newborns in NICU and all other newborns in TCU and RCU.

The results presented in our paper show differences when compared to some of the other studies (Table 6). In

Table 4. Distribution of the prescriptions among the neonates admitted to TCU and RCU

\begin{tabular}{|c|c|c|c|c|}
\hline \multirow[t]{2}{*}{ Category of medicines } & \multicolumn{2}{|c|}{$\begin{array}{c}\mathrm{P}_{4} \\
\text { (ne } \mathrm{n}=152 \text { ) }\end{array}$} & \multicolumn{2}{|c|}{$\begin{array}{c}\mathrm{P}_{5} \\
\text { (ftne } \mathrm{n}=48 \text { ) }\end{array}$} \\
\hline & $\mathrm{n}$ & $\%$ & $\mathrm{n}$ & $\%$ \\
\hline On-label & 148 & 84.1 & 106 & 96.4 \\
\hline Off-label & 28 & 15.9 & 4 & 3.6 \\
\hline Unlicensed & 0 & 0 & 0 & 0 \\
\hline All medicines & 176 & 100 & 110 & 100 \\
\hline
\end{tabular}

$\mathrm{P}_{4}$ - prescriptions for neonates in TCU; $\mathrm{P}_{5}$ - prescriptions for full term neonates in RCU, rooming in with their mothers; ne nnumber of neonates; ftne $\mathrm{n}$ - number of full term neonates. 
these studies, off-label drug use varies between $7-65 \%$ and unlicensed use between 4.4-28\%, which is not surprising due to the variability the study design, inconsistency between the settings, in terms of the severity of diseases and indications among the patients (maternity hospital vs. pediatric hospital care), category of Unit (NICU vs. Ordinary Unit), etc. Moreover, the definitions of offlabel and unlicensed use vary between different surveys, therefore the comparison of the results of these studies is not directly possible.

Table 5. Five most frequently prescribed off-label drugs of all prescriptions

\begin{tabular}{cc}
\hline \hline Rank & $\begin{array}{c}\text { Five most frequently prescribed off- } \\
\text { label drugs }\end{array}$ \\
\hline 1 st & Imipenem \\
3rd & Diazepam \\
4 th & Gentamicin \\
5 th & Indomethacin \\
\hline
\end{tabular}

Higher off-label and unlicensed prescription rates has been found in settings offering more sophisticated care, or in which the patients present more complex disease processes (Czarniak et al., 2015). In an international literature review (Lindell-Osuagwu et al., 2009) it was noted that 88$90 \%$ of infants in NICU-s receive off-label or unlicensed drugs. The results of our study confirm these findings, with a significant higher rate of off-label prescriptions found in NICU compared to TCU and RCU.

Compared to other studies, there is variability between the results of off-label and unlicensed prescription in NICU-s, with higher proportion of off-label prescriptions, but lower unlicensed prescriptions found in our study compared to those conducted in England (Conroy et al.,1999), Australia (O’Donnell et al., 2002), Italy (Dell'Aera et al.,
2007), Ireland (Kieran et al., 2014) and Portugal (Silva et al., 2015). On the other hand, in a France study (Nguyen et al., 2011) involving neonatal units without intensive care, the rate of off-label prescriptions was $29.4 \%$, which is pretty much higher compared to our study (in TCU and RCU). With regards to unlicensed prescriptions, they comprised $16.6 \%$ of total prescriptions, whereas there were no unlicensed prescriptions in our study (in TCU and RCU).

In a previous study conducted in similar neonatal units (NICU and intermediate-level wards of neonatal care) (Lass et al., 2011), the rate of off-label prescriptions was almost the same $(65 \%)$, but compared to our study, the extent of unlicensed prescriptions was totally different, with $22 \%$ of all prescriptions being unlicensed.

The small number of unlicensed medicines use found in our study was probably due to the tide regulation about unlicensed medicine use in our country.

Direct comparison of different study results for drug utilization is often not possible, as well, due to the lack of uniform methods, for example, which drugs are to be included in the study. In a German study (Neubert et al., 2010), the median number of prescriptions per newborn was 11.1, which is almost twofold higher rate compared to our results for the drug prescriptions in the NICU. High amount of drugs use was also reported in recent studies conducted in Finland (Lindell-Osuagwu et al. 2014), 9 prescriptions/newborn and Spain (Blanco-Reina et al. 2016), 8.3 prescription/newborn. Whilst, in some other studies the drug utilization was smaller, with a median number of 5.5 prescriptions/newborn in Italy (Dell'Aera et al., 2007) and 4 prescriptions/newborn in Ireland (Kieran et al., 2014).

With regards to the most frequently prescribed offlabel medicines, indomethacin and furosemide were prescribed off-label for different indications (indomethacin for patent ductus arteriosus and furosemide for chronic lung disease), gentamicin was regarded as off-label for dose and/or frequency, diazepam formulation for intravenous use was used for different route of administration

Table 6. Studies of off-label and unlicensed drug use in hospital setting of neonatal health care

\begin{tabular}{ccccl}
\hline \hline $\begin{array}{c}\text { Number of } \\
\text { patients in } \\
\text { study }\end{array}$ & $\begin{array}{c}\text { Total } \\
\text { number of } \\
\text { prescriptions }\end{array}$ & $\begin{array}{c}\text { Off-label } \\
\text { medicines uses } \\
(\%)\end{array}$ & $\begin{array}{c}\text { Unlicensed } \\
\text { medicines uses } \\
(\%)\end{array}$ & \multicolumn{1}{c}{ Country, year and reference } \\
\hline 70 & 455 & 55 & 10 & England, 1999 (Conroy et al., 1999) \\
293 & 1017 & 44 & 28 & Holland, 2001 ('t Jong et al., 2001) \\
97 & 1442 & 47 & 11 & Australia, 2002 (O'Donnell et al., 2002) \\
35 & 176 & 51 & 12 & Italy,2007 (Dell'Aera et al., 2007) \\
108 & 628 & 7 & 11 & Finland, 2009 (Lindell-Osuagwu et al., 2009) \\
490 & 1981 & 65 & 22 & Estonia, 2011 (Lass et al., 2011) \\
110 & 900 & 39 & 19 & 2014, Ireland (Kieran et al., 2014) \\
218 & 1011 & 52.7 & 4.4 & 2015, Portugal (Silva et al., 2015) \\
\hline
\end{tabular}

Макед. фарм. билт., 62 (2) 65 - 72 (2016) 
(rectally in the case of neonatal seizures) while imipenem was used out of age range (it is licensed for use in infants above 3 months of age).

All off-label and unlicensed medicines were administered according to the current Guidelines, evidencebased and regularly updated but, the level of evidence for majority of the recommendations was not very high. These data further confirm the findings of previous researchers in the field, that there is a lack of knowledge about the efficacy and safety in neonatal therapy. In general, off label use pattern in the one hand attempts to provide appropriate dosage form for patient but on the other hand runs the risk of errors in compounding, dispensing or administration. The bioavailability of such adjusted medicine is unpredictable and there may be no compatibility and/or stability data available.

The specific difficulties for the therapy are in close link to the diagnostic dilemmas for newborns, and the appropriateness of the level of care. Important point for discussion is the cross-matching between the Guidelines and availability of licensed and on-label medicines (Guyatt et al., 1999; Ansani et al., 2006; Glasziou et al., 2007).

\section{Conclusions}

The results presented above present only the "top of the iceberg" but there is a lot of work that has to be done in the near future. Nowadays, a growing and stronger demand is observed in off-label medicines, they will be in continuum prescribed within the neonatal therapy and this practice will not be excluded from the evidence based Guidelines. In fact, the majority of off label uses have made substantial progress in treating newborns, especially those critically ill and premature ones. However, the evidence for their efficacy and safety is not on high level, and information on adverse effects is lacking. All these facts require further work and research in this area. This particular study has additionally initiated in depth analysis of the type of pharmaceutical formulations, unlicensed reformulation before administration which were mostly used, pharmacological groups, license status, indications, etc., and the results are intended to be published later as continuum on this topic. Despite the considerable off-label medicines use there is little guidance for prescribers in neonatology

Improving drug information for physicians but also for the public is one of the crucial activities in the field of neonatal pharmacotherapy. It could be only achieved by identification of real needs within the neonatal treatment, intensive and systematic research agenda and by providing a National Guideline on off-label use areas in pediatric medicine, which in turn should result in more useful new knowledge to facilitate future treatment decisions.

\section{References}

't Jong, G.W., Vulto, A.G., de Hoog, M., Schimmel, K.J.M., Tibboel, D., and van den Anker, J.N., 2001. A Survey of the Use of Off-Label and Unlicensed Drugs in a Dutch Children's Hospital. Pediatrics 108, 1089-1093.

Ansani, N., Sirio, C., Smitherman, T., Fedutes-Henderson, B., Skledar, S., Weber, R.J., Zgheib, N., and Branch, R., 2006. Designing a strategy to promote safe, innovative off-label use of medications. Am. J. Med. Qual. 21, 255-261.

Bavdekar, S.B. \& Gogtay, N.J., 2005. Unlicensed and off-label drug use in children. Journal of postgraduate medicine 51(4), pp.249-52.

Blanco-Reina, E., Medina-Claros, A.F., Vega-Jiménez, M.A., Ocaña-Riola, R., Márquez-Romero, E.I., and RuizExtremera, Á., 2016. Drug utilization pattern in children and off-label use of medicines in a pediatric intensive care unit. Med. Intensiva 40, 1-8.

Conroy, S., McIntyre, J., and Choonara, I., 1999. Unlicensed and off label drug use in neonates. Arch. Dis. Child. Fetal Neonatal Ed. 80, F142-F144; discussion F144-F145.

Cuzzolin, L., Atzei, A., and Fanos, V., 2006. Off-label and unlicensed prescribing for newborns and children in different settings: a review of the literature and a consideration about drug safety. Expert Opin. Drug Saf. 5, 703-718.

Czarniak, P., Bint, L., Favie, L., Parsons, R., Hughes, J., Sunderland, B., 2015. Clinical setting influences off-label and unlicensed prescribing in a paediatric teaching hospital. PloS one, 10(3), p.e0120630.

Dell'Aera, M., Gasbarro, A.R., Padovano, M., Laforgia, N., Capodiferro, D., Solarino, B., Quaranta, R., and Dell'Erba, A.S., 2007. Unlicensed and off-label use of medicines at a neonatology clinic in Italy. Pharm. World Sci. 29, 361-367.

Dresser, R., Frader, J., 2009. Off-label prescribing: A call for heightened professional and government oversight. J. Law, Med. Ethics 37, 476-486.

European Commission, 2013. Better medicines for children: From concept to reality. Report From The Commission to The European Parliament And The Council. Available at: http:/ec.europa.eu/health/files/paediatrics/2013_com443/ paediatric_report-com(2013)443_en.pdf [Last accessed: April 11, 2016].

Gazarian, M., Kelly, M., McPhee, J.R., Graudins, L. V, Ward, R.L., and Campbell, T.J., 2006. Off-label use of medicines: consensus recommendations for evaluating appropriateness. Med. J. Aust. 185, 544-548.

Glasziou, P., Chalmers, I., Rawlins, M., and McCulloch, P., 2007. When are randomised trials unnecessary? Picking signal from noise. BMJ 334, 349-351.

Guyatt, G.H., Sinclair, J., Cook, D.J., and Glasziou, P., 1999. Users' guides to the medical literature: XVI. How to use a treatment recommendation. Evidence-Based Medicine Working Group and the Cochrane Applicability Methods Working Group. JAMA 281,

Kieran, E.A., O’Callaghan, N., O’Donnell, C.P.F., 2014. Unlicensed and off-label drug use in an Irish neonatal intensive care unit: a prospective cohort study. Acta Paediatr. 103, e139-e142.

Kimland, E., Bergman, U., Lindemalm, S., and Böttiger, Y., 2007. Drug related problems and off-label drug treatment in children as seen at a drug information centre. Eur. J. Pediatr. $166,527-532$. 
Lass, J., Käär, R., Jõgi, K., Varendi, H., Metsvaht, T., and Lutsar, I., 2011. Drug utilisation pattern and off-label use of medicines in Estonian neonatal units. Eur. J. Clin. Pharmacol. 67, 1263-1271.

Lindell-Osuagwu, L., Korhonen, M.J., Saano, S., HelinTanninen, M., Naaranlahti, T., and Kokki, H., 2009. Offlabel and unlicensed drug prescribing in three paediatric wards in Finland and review of the international literature. J. Clin. Pharm. Ther. 34, 277-287.

Lindell-Osuagwu, L., Hakkarainen, M., Sepponen, K., Vainio, K., Naaranlahti, T., and Kokki, H., 2014. Prescribing for off-label use and unauthorized medicines in three paediatric wards in Finland, the status before and after the European Union Paediatric Regulation. J. Clin. Pharm. Ther. 39, 144153.

Miller, M.R., Robinson, K.A., Lubomski, L.H., Rinke, M.L., and Pronovost, P.J., 2007. Medication errors in paediatric care: a systematic review of epidemiology and an evaluation of evidence supporting reduction strategy recommendations. Qual. Saf. Health Care 16, 116-126.

Ministry of Health, R.M., n.d. Guidelines for practicing evidencebased medicine - Ministry of Health, Republic of Macedonia. Available at: http://zdravstvo.gov.mk/upatstva_update/ [Last accessed: April 8, 2016].
Neubert, A., Lukas, K., Leis, T., Dormann, H., Brune, K., and Rascher, W., 2010. Drug utilisation on a preterm and neonatal intensive care unit in Germany: a prospective, cohort-based analysis. Eur. J. Clin. Pharmacol. 66, 87-95.

Nguyen, K.-A., Claris, O., and Kassai, B., 2011. Unlicensed and off-label drug use in a neonatal unit in France. Acta Paediatr. 100, 615-617.

O’Donnell, C.P.F., Stone, R.J., and Morley, C.J., 2002. Unlicensed and off-label drug use in an Australian neonatal intensive care unit. Pediatrics 110, e52.

Palčevski, G., Skočibušić, N., and Vlahović-Palčevski, V., 2012. Unlicensed and off-label drug use in hospitalized children in Croatia: A cross-sectional survey. Eur. J. Clin. Pharmacol. 68, 1073-1077.

Pandolfini, C., and Bonati, M., 2005. A literature review on offlabel drug use in children. Eur. J. Pediatr. 164, 552-558.

Silva, J., Flor-De-Lima, F., Soares, H., and Guimaraes, H., 2015. Off-Label and Unlicensed Drug Use in Neonatology: Reality in a Portuguese University Hospital. Acta Med. Port. 28, 297-306.

Ufer, M., Kimland, E., and Bergman, U., 2004. Adverse drug reactions and off-label prescribing for paediatric outpatients: a one-year survey of spontaneous reports in Sweden. Pharmacoepidemiol. Drug Saf. 13, 147-152.

\title{
Резиме
}

\section{Студија неодобрена употреба на лекови и употреба на нерегистрирани лекови во одделите за неонатологија}

\author{
Елизабета Зисовска ${ }^{1 *}$, Блерина Коши ${ }^{2,3}$, Рената Славеска Раички ${ }^{3}$ \\ ${ }^{1}$ Универзииееиска Клиника за іинеколоіија и акушерсииво, Мајка Тереза, 1000 Скойје, \\ Рейублика Макеоонија

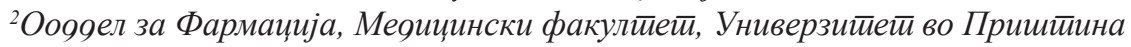

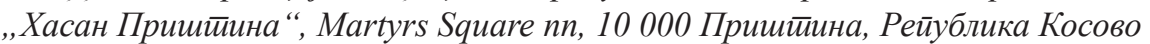

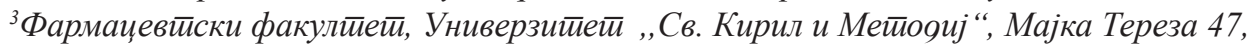 \\ 1000 Скойје Рейублика Макеоонија
}

Клучни зборови: новородени, пропишување, лекови користени надвор од означувањето, нелиценцирани лекови

Покрај сите напори во неонаталната терапија да се подобри употребата на лиценцирани лекови кои се користат согласно нивната ознака, се́ уште има висок процент и потреба за неодбрена употреба на лиценцирани лекови и употреба на нелиценцирани лекови. Затоа, главна цел на оваа студија е да се прикаже употребата на лиценираните лекови за неодобрена употреба и на нелиценцираните лекови во терапевтските области од неонатологијата во Одделот за неонатологија при Универзитетска клиника за гинекологија, Скопје, Република Македонија.Сите анализирани лекови се дадени во согласност со тековните Клинички упатства засновани на докази. Во текот на тримесечен период во 2014/15 година дадени се 1595 прескрипции , што изнесува 13,99 прескрипции/новороденче во текот на престојот во болница, Од нив, 535(33.3\%) биле лекови користени според означувањето, 1052 (66\%) се лекови надвор од означувањето, и 11 прескрипции $(0,7 \%)$ биле нелиценцирани лекови. Резултатите од оваа студија покажуваат 
висока стапка на користење на лекови надвор од означувањето во неонаталната терапија. Овој резулатат претставува само „врв од санта мраз“, што бара подетална анализа која што постепено треба да прерасне во национален водич во областа на примена на лиценирани лекови за неодобрена употреба во педијатриската медицина, посебно за критично болните новородени за кои се пропишуваат многу повеќе лекови. 